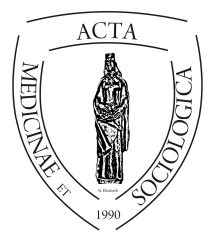

Acta Medicinae et

Sociologica (2018)

UNIVERSITY OF

DEBRECEN

Vol. 9. No. 27. (110-124)

doi: $10.19055 / \mathrm{ams} .2018 .9 / 27 / 8$

FACULTY OF

HEALTH

NYÍREGYHÁZA

\title{
Társas kapcsolatok Nyíregyházán 2008-2018
}

\section{Huszti Éva ${ }^{1}$}

${ }^{1}$ főiskolai docens. Debreceni Egyetem Egészségügyi Kar, 4400 Nyíregyháza, Sóstói u. 2-4.

\section{INFO ABSTRACT}

Huszti Éva

huszti.eva@foh.unideb.hu

Keywords

Social network

Social support

Social connections in Nyiregyhaza between 2008-2018. As since 2008, also in the new data collecting period (20172018), adult people in Nyíregyhaza were asked their social relationships. This paper shows some aspects of the composition of the egocentric network of adult inhabitants of the city. It contains information about the friendships and the social support system of the respondents. The study also focuses on to describe how frequent is among inhabitants that they go out, visit their friends or neighbours, whether they are member of different kind of organizations. At first, the study deals with results from 2018 and then it gives detailed information about the main characteristics of some aspects of the egocentric network of adult people and it provides data on changes in the relationship system over the past ten years.

Kulcsszavak

Kapcsolathálózat

Társas támogatottság
Absztrakt. Ahogyan 2008 óta minden adatfelvétel alkalmával, a jelenlegi 2017-18-as adatfelvétel idején is külön kérdésblokkban kérdeztük Nyíregyháza felnőtt lakosságát társas kapcsolataikról. A tanulmány bemutatja a megkérdezettek társas kapcsolatrendszerének összetételét, baráti társaságuk kiterjedtségét, továbbá azt, hogy milyen típusú támogatásokra számíthatnak a kapcsolatrendszerükben található személyektől. Az életminőség azon aspektusára is fókuszál a tanulmány, hogy a nyíregyházi felnőtt népességre mennyire jellező az, hogy járnak-e társaságokba, klubokba, tagjai-e civil szervezeteknek. A tanulmányban elöször a legfrissebb, azaz 2018-as nyíregyházi adatfelvétel eredményei kerülnek közlésre, majd a nyíregyházi felnőtt lakosság társas kapcsolatainak mintázatát mutatja be az elmúlt tív évre vonatkoztatva, kiemelve az állandó jellegzetességeket és a változásokat.

Ez a tanulmány a Nyíregyháza város életminősége - Háztartáspanel kutatás Egészségi állapot felmérése keretében készült. 


\section{Bevezetés}

A Nyíregyháza életminőségét vizsgáló háztartás panel vizsgálat kérdéskörei közé már az első adatfelvétel idején, 2008-ban bekerült a társas kapcsolatok vizsgálata is. Így lehetőség nyílt arra, hogy több kérdés, több dimenzió mentén vizsgáljuk meg az ország hetedik legnagyobb városában élő felnőtt népesség társas kapcsolathálózatának mintázatát. A társas kapcsolatok jelentőségét egyrészt az adja, hogy ezeken a kapcsolatokon társadalmi erőforrások áramlanak. Másrészt, mint ahogyan azt már több kutatás is alátámasztotta, azok az egyének, akik bármilyen társadalmi támaszt kapnak, elégedettebbek az életkörülményeikkel, boldogabbak és kiegyensúlyozottabbak, pozitívan értékelik életminőségüket, tehát a társas támogatottság mértéke meghatározó része a szubjektív életminőségnek (Cassel, 1974, 1967 in Albert - Dávid, 2001, Utasi, 2008).

A tanulmányban először a legfrissebb, azaz 2018-as nyíregyházi adatfelvétel eredményei kerülnek közlésre, majd a nyíregyházi felnőtt lakosság társas kapcsolatainak mintázatát mutatja be az elmúlt tív évre vonatkoztatva, kiemelve az állandó jellegzetességeket és a változásokat.

\section{Minta és módszer}

A vizsgált minta rövid bemutatása: a 2018-as adatfelvétel idején a megkérdezettek 56\%-a nő, családi állapotukat tekintve többségük (48\%-uk) házas, 12\%-uk élettárssal él. Negyedük (23\%) nőtlen, hajadon, 7\%-uk elvált és 10\%-uk özvegy. A megkérdezettek 16\%-a maximum 8 általános iskolai végzettséggel rendelkezik, 21\% szakiskolai szakképesítéssel, érettségivel 25,5\%. Érettséginél magasabb iskolai végzettséggel, de nem felsőfokú végzettséggel a minta 10\%-a rendelkezik. Főiskolai, egyetemi vagy ettől magasabb végzettsége a megkérdezettek 27\%-ának van. A megkérdezettek átlagéletkora 45 év. A minta ilyetén megoszlása miatt a 2018-as adatfelvétel során készült adatbázist nemre, korra és iskolai végzettségre súlyoztuk az elemzések során. (Fábián és munkatársai, 2018; Huszti és mtsai, 2018)

Ahogyan 2008 óta minden adatfelvétel alkalmával, a jelenlegi 2017-18-as adatfelvétel idején is külön kérdésblokkban kérdeztük Nyíregyháza felnőtt lakosságát társas kapcsolataikról. Kíváncsiak voltunk, hogy hány barátjuk van a megkérdezetteknek; tudnak-e segítséget kérni bizonyos élethelyzetekben; mennyire vesznek részt a város életében, azaz járnak-e társaságokba, klubokba, tagjai-e civil szervezeteknek, stb. A tanulmány a kérdőívben alkalmazott kérdések sorrendjében dolgozza fel az adatokat.

\section{Barátok száma 2018}

A „Hány barátja van Önnek?” kérdésre 365 fó válaszolt, ők átlagosan 5,12 barátról számoltak be, leggyakrabban 2 barátot említettek a megkérdezettek (Std.=6,464, Min.=0, Max=80). Az országos vizsgálatok szerint 2015-ben az átlagos barátszám a 
felnőtt magyar lakosság körében 3 volt (Albert-Dávid, 2016). A barátok számát tekintve a nyíregyházi mintában nincs jelentős különbség a férfiak és a nők között $(5,7$ vs. 4,7), viszont a különböző korcsoportok közötti különbség szignifikáns $(\mathrm{p}=0,001)$ : míg a 18-29 évesek átlagosan 6,6 barátról számoltak be, a 70 éves és idősebb válaszadók átlagosan 3 baráttal rendelkeznek. Az iskolai végzettséget tekintve megállapítható, hogy minél magasabb iskolai végzettséggel rendelkezik a megkérdezett, annál magasabb az általa említett barátok száma. A különbség azonban nem szignifikáns. A barátok számát négy csoportra bontva (1) 0 barát, 2) 1-4 barát, 3) 5-9 barát, 4) 10 vagy annál több barát) láthatjuk, hogy a baráttal nem rendelkezők aránya $11 \%$, azaz minden tizedik válaszadónak nincs egyetlen barátja sem. A megkérdezetteknek több mint fele (54\%) 1-4 barátról számolt be, 25\%-uk 5-9 baráttal bír és $10 \%$-uk a baráthalmozó kategóriába sorolható a legalább tíz baráttal.

\section{Társas támogatottság 2018}

A társas támogatottságot a következő kérdések mentén vizsgáltuk:

1) „Van-e Önnek olyan családtagja, rokona, aki segítséget nyújt vagy nyújtott hivatalos ügyintézéshez?"

2) „Van-e Önnek olyan családtagja, rokona, aki segítséget nyújt vagy nyújtott iskoláztatással, továbbtanulással kapcsolatban?"

3) „Van-e Önnek olyan családtagja, rokona, aki segítséget nyújt vagy nyújtott egy jó állás, munkahely megszerzéséhez?"

4) „Van-e Önnek olyan családtagja, rokona, aki segítséget nyújt vagy nyújtott betegség eseténe jó orvost szerezni?"

5) „Van-e Önnek olyan barátja, ismeröse, aki segítséget nyújt vagy nyújtott hivatalos ügyintézéshez?"

6) „Van-e Önnek olyan barátja, ismerőse, aki segítséget nyújt vagy nyújtott iskoláztatással, továbbtanulással kapcsolatban?”

7) „Van-e Önnek olyan barátja, ismeröse, aki segítséget nyújt vagy nyújtott egy jó állás, munkahely megszerzéséhez?”

8) „Van-e Önnek olyan barátja, ismeröse, aki segítséget nyújt vagy nyújtott betegség eseténe jó orvost szerezni?"

A 2018-as adatok szerint a megkérdezettek 65\%-a tud segítséget kérni hivatalos ügyek intézése esetén családtagjaitól, rokonaitól és $43 \%$-uk barátaiktól, ismerőseiktől.

Iskoláztatással, továbbtanulással kapcsolatban a megkérdezettek 41,5\%-ának van olyan családtagja, rokona, akitől tud segítséget kérni. 27\%-uk mondta, hogy baráttól, ismerőstől is tud ilyen esetben segítséget kérni.

Fontos kérdés lehet, hogy van-e az ember közelében olyan, akitől segítséget tud kérni egy jó állás vagy munkahely megszerzések esetén. A megkérdezettek 41\%-a válaszolta azt, hogy van olyan családtagja, rokona, akitől ilyen helyzetben segítséget tud vagy tudott nyújtani. $43 \%$ azok aránya is, akik rendelkeznek olyan baráttal, ismerőssel, aki tud segítséget nyújtani ilyen esetben. 
A megkérdezettek jelentős részének (73\%) van olyan családtagja, rokona, akitől betegség esetén tud segítséget kérni ,jó orvos szerzésében”. 49,5\%-uk mondta azt, hogy barátja, ismerőse van, akitől betegség esetén segítséget tud kérni.

\section{Kapcsolattartás rokonokkal, barátokkal, szomszé- dokkal 2018}

A rokonokkal, barátokkal, szomszédokkal való kapcsolattartást a korábbi évekhez hasonlóan a következő kérdések mentén vizsgáltuk:

„Milyen gyakran beszélget a szomszédjaival?” (1) mindennap, 2) hetente 1-2 alkalommal, 3) havonta 1-2 alkalommal, 4) ritkábban, mint havonta, 5) soha).

„Milyen gyakran találkozik barátaival, rokonaival, akik máshol élnek, mint Ön?” (1) mindennap, 2) hetente 1-2 alkalommal, 3) havonta 1-2 alkalommal, 4) ritkábban, mint havonta, 5) soha).

A 2018-as adatok alapján elmondható, hogy a megkérdezettek 59\%-a beszélget gyakran, azaz naponta, vagy hetente 1-2 alkalommal a szomszédaival. A válaszoló nyíregyháziak 45\%-a találkozik naponta, vagy hetente 1-2 alkalommal olyan rokonokkal, akik máshol élnek, mint a megkérdezett, azaz nem ugyannak a háztartásnak a tagjai. A barátokkal való gyakori találkozásról ugyancsak a megkérdezettek 45\%-a nyilatkozott. 47\%-uk néha, 8\%-uk pedig soha nem találkozik azokkal a barátaikkal, akik nem ott élnek, ahol ők. Ez utóbbi valószínüleg az internetes barátokat takarhatja.

Egy másik kérdés kapcsán megállapítható, hogy a megkérdezettek 46\%-a mondta azt, hogy a szomszédban, vagy a környéken, a közelben élők közül nincs egy barátja sem.

\section{Magántársasági összejövetelek 2018}

Mint ahogyan korábban is, a magántársasági összejöveteleknek három aspektusát vizsgáltuk: milyen gyakran mennek vendégségbe, látogatóba a megkérdezettek; milyen gyakran fogadnak vendégeket, látogatókat; milyen gyakran találkoznak barátaikkal, ismeröseikkel nyilvános helyeken (étterem, sörözö, presszó, stb.).

A megkérdezettek 60\%-a mondta azt, hogy gyakran (hetente, havonta) megy vendégségbe, látogatóba. $66 \%$ azok aránya, akik gyakran fogadnak vendégeket, látogatókat otthonukban. 2018-ban a megkérdezettek majdnem fele (48\%) mondta azt, hogy heti vagy havi rendszerességgel megy étterembe, sörözőbe, presszóba, és egyéb nyilvános helyekre. 


\section{Közélet. Tagság szervezett közösségekben 2018}

A megkérdezettek 11\%-a tagja sportklubnak, 3\%-a valamilyen szomszédsági csoportnak, 2\%-a vesz részt müvészeti csoport tevékenységében, 9\%-uk tartozik vallási közösséghez. 9\%-uk valamilyen szabadidős klubba jár, 4\% pedig jótékonysági szervezethez tartozik. A megkérdezettek 1\%-a mondta azt, hogy tagja valamilyen pártnak. Az egyéb kategóriát a megkérdezettek 5\%-a választotta.

\section{Párkapcsolatok és bizalmasok 2018}

A társas kapcsolatokat, társas támogatórendszert vizsgálva fontos kérdés lehet, hogy az egyénnek van-e partnerkapcsolata és van-e olyan bizalmasa, akivel megbeszélhet számára fontos, intim kérdéseket is. A partnerkapcsolat megléte egyszerüen leírható azzal, hogy a megkérdezettnek van-e házastársa, vagy élettársa, azaz milyen családi állapotot mondott a kérdezés során. 2018-ban a megkérdezett nyíregyházi felnőttek $60 \%$-a mondta azt, hogy házastárssal (48\%) vagy élettárssal (12\%) él.

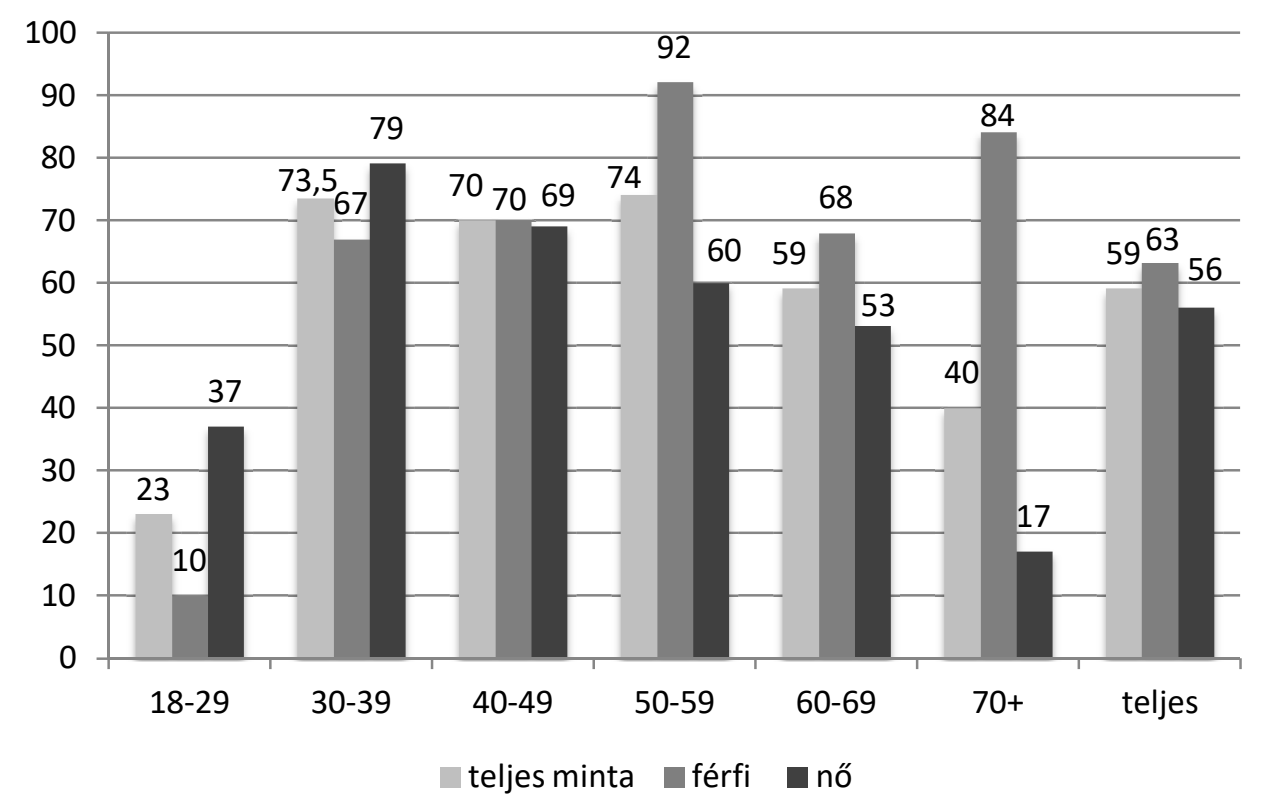

Forrás: Nyíregyháza Életminősége, 2018

1. ábra: A partnerkapcsolatban élők megoszlása nemek és korcsoportok szerint.

Míg a teljes mintát vizsgálva nem mutatható ki szignifikáns különbség a férfiak és nők parnerkapcsolatainak arányában, addig a korcsoportos bontás világosan mutatja a lényeges eltéréseket $(\mathrm{p}=0,000)$ : a mintába került 18-29 éves nők 37\%-a él társkapcsolatban, míg a férfiak esetében ebben a korcsoportban ez az arány csupán $10 \%$. A 
házastárssal vagy élettárssal élök aránya az 50-59 évesek csoportjában a legmagasabb (74\%), de itt is jelentős nemi eltérésekkel (férfiak 92\%, nők 60\%). Érdemes megfigyelni, hogy a negyven év alatt még a nők nagyobb hányada él partnerkapcsolatban, ötven év fölött viszont jelentősen csökken körükben a társsal élők aránya. A 70 éves és idősebb válaszadók esetében látható a legnagyobb különbség: a férfiak 84\%-a, míg a nőknek csupán 17\%-a él társsal ebben az életkorban. Ennek magyarázata alapvetően a férfiak halandósági adataiban keresendő.(1. ábra)

A fentebbi adatok nem térnek el jelentősen a 2015-ben országos reprezentatív mintán végzett kutatás eredményeitől, ahol ugyancsak hasonló tendenciák voltak kimutathatók (Albert-Dávid, 2016).

\section{Társas kapcsolatok Nyíregyházán 2008-2018}

A tanulmány következő részében a társas kapcsolatoknak az elmúlt tíz évben történő jellegzetességei kerülnek részletezésre. Ennek során a következő témák idősoros (2008, 2010, 2012, 2015, 2018) elemzése történik a rendelkezésre álló adatok alapján:

- baráti kapcsolatok,

- társas támogatottság,

- rokonokkal, barátokkal, szomszédokkal való kapcsolattartás gyakorisága,

- magántársasági összejövetelek,

- $\quad$ szervezeti tagság

Az elemzések alapját a korábban már ismertetett, megjelent tanulmányok adják.

\section{Baráti kapcsolatok alakulása Nyíregyházán (2008-2018)}

A társas kapcsolatok között lényeges szerepe van a baráti kapcsolatoknak. A barátságok különbözőek lehetnek: az intim, közeli barátságoktól a lazább, felületesebb, „haveri” kapcsolatokig terjedhetnek. Mégis, pusztán az, hogy van-e valakinek olyan „másik” a közelében, akire barátjaként gondol, fontos mutatója a személyes kapcsolathálózatnak. A jó barátok a családon kívüli olyan kapcsolatok, melyek biztonságot nyújtanak az egyénnek, kölcsönös segítségnyújtást, intim és bizalmas kapcsolatot jelentenek (Granovetter, 1973, Lin 2008, Albert-Dávid 2007). Nyíregyházán a vizsgált tíz év során az átlagos barátok számát tekintve ingadozást figyelhettünk meg: legmagasabb barátszámot 2010-ben mértünk, mikor a megkérdezett felnőtt népesség átlagosan 6 barátról számolt be. Legkevesebbet 2015-ben mértünk, ekkor 4,7 volt az említett barátszám. A jelenség azonban nem szokatlan, hiszen a hazai vonatkozó vizsgálatok is hasonló mozgásokat detektáltak: 2011-ben 5,5 barátot mértek, 2015ben pedig 3-at. Mint láttuk, Nyíregyházán nem volt ilyen nagy az ingadozás mértéke. A férfiak és nők közötti különbség a barátok számát tekintve ugyanilyen ingadozó képet mutat, viszont a férfiak esetében 2008-ban és 2018-ban mértük a legmagasabb átlagos barátszámot (6), addig a nők esetében 2010 volt a „kiugró” év (6). 
A barátok számát négy kategóriára bontva az alábbi ábra mutatja: a legelső és az utolsó két mérés idején az 1-4 baráttal rendelkezők aránya volt a legmagasabb. 2010-ben az 5-9 baráttal rendelkezők voltak a legtöbben a vizsgált mintában, míg 2012-ben a legalább 10 baráttal bírók. A baráttal nem rendelkezők aránya viszonylag statikus az első négy mérési hullámban (20-21-16-20\%), míg legutóbbi mérés eltér el az előzőektől: a 2018-as adatok szerint a megkérdezetteknek tizede sorolható a baráttal nem rendelkezők körébe.(2. ábra)

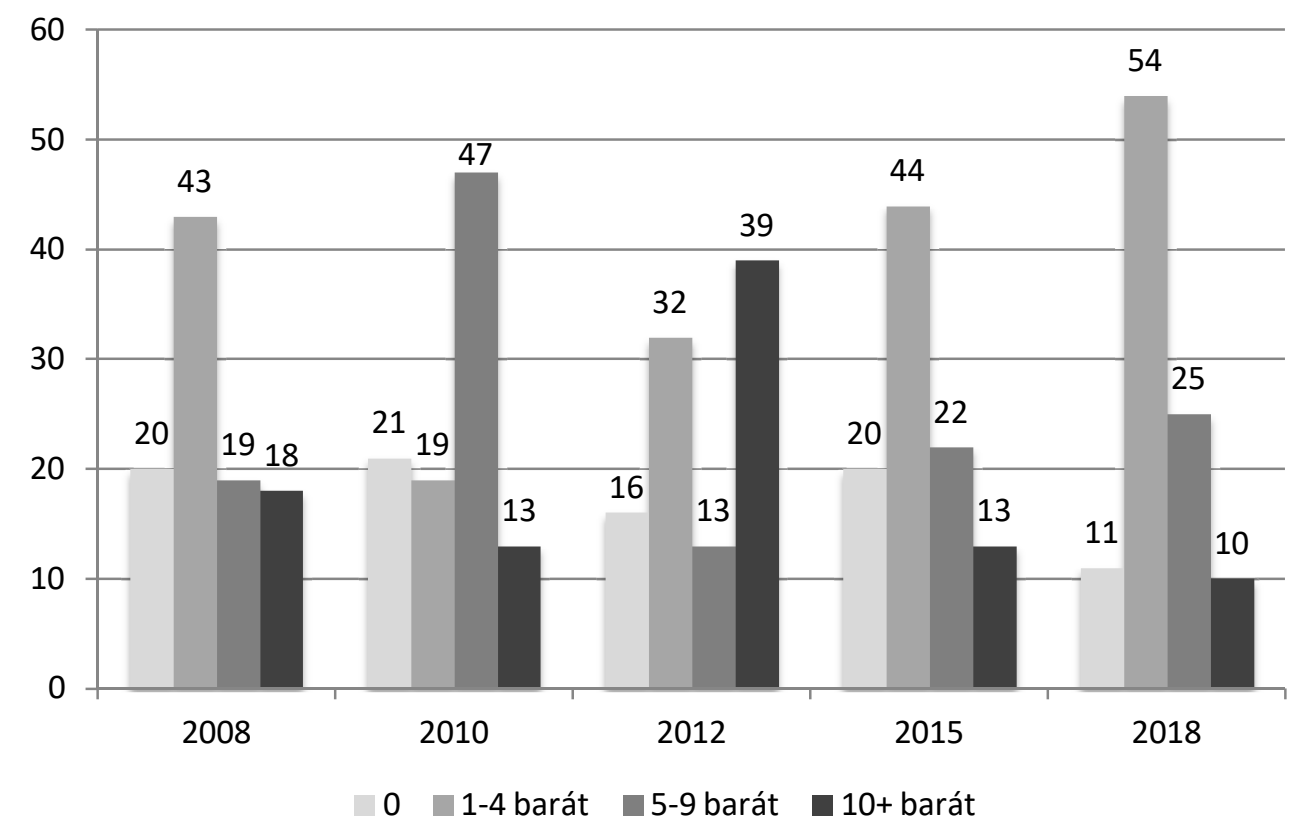

Forrás: Nyíregyháza életminösége, 2008, 2010, 2012, 2015, 2018

2. ábra: Barátok száma Nyíregyházán 2008-2018.

A barátok számát korcsoportonként is megvizsgáltuk: az adatok szerint az évek során nem történt lényeges változás az egyes korcsoportokban mért átlagos barátszámokban. Minden vizsgált évben a fiataloknak volt a legtöbb barátjuk és a kor előrehaladtával folyamatosan csökkenő tendenciát figyelhettünk meg. Két vizsgált évben azonban volt olyan korcsoport, mely kiugrott ebböl a csökkenő tendenciából, megtörve ezzel a linearitást: 2010-ben az akkor 50-59 éveseknek több barátjuk volt, mint az egyel fiatalabb korcsoportnak (6,5 vs. 5,9). 2018-ban pedig a most 60-69 évesek számoltak be lényegesen több barátról, mint a 40-49 illetve az 50-59 éves korosztály (6,3 vs. 3,4 ill. 4,1). A korcsoportok közötti eltérések minden esetben szignifikánsak. (3. ábra) 


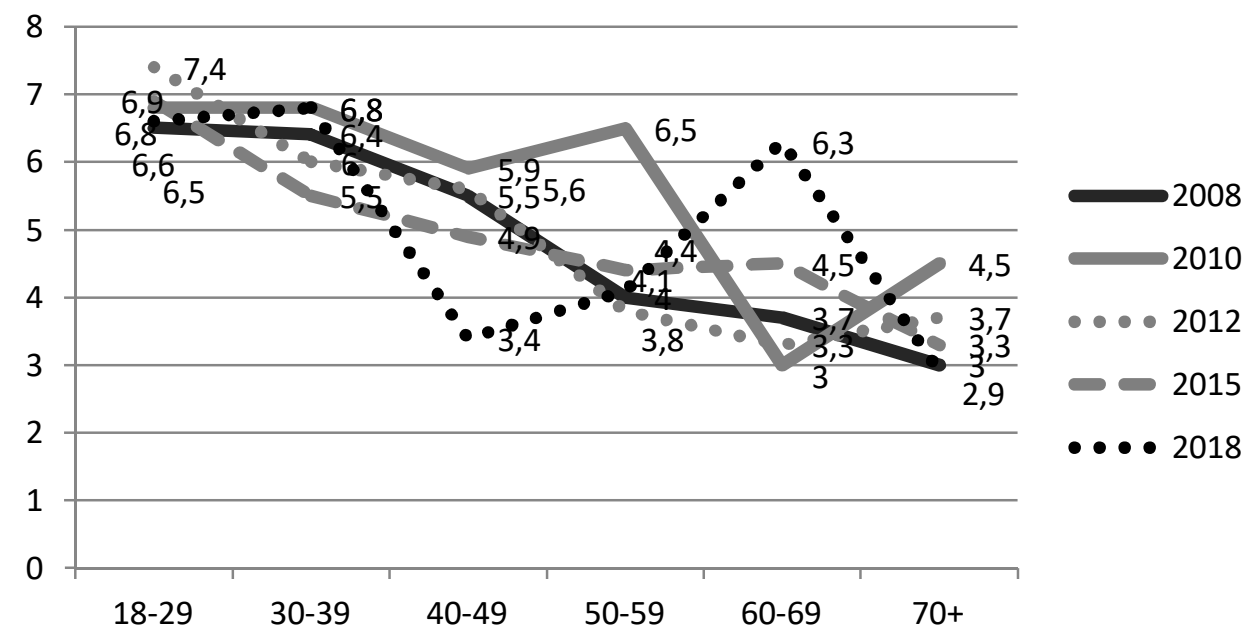

Forrás: Nyíregyháza életminösége, 2008, 2010, 2012, 2015, 2018

3. ábra: A barátok számának változása a különböző korcsoportokban 2008-2018.

\section{Társas támogatottság alakulása Nyíregyházán 2008-2018}

A Nyíregyháza életminősége kutatássorozatban négy kérdés mentén vizsgáltuk, hogy a megkérdezett egyéneknek van-e olyan családtagja, rokona, illetve barátja vagy ismerőse, akitől bizonyos esetekben tud segítséget kérni. A társas támogatást nyújtó személyek számáról és egyéb szociodemográfiai jellemzőiről e kérdések esetén nem gyüjtöttünk adatokat. Kérdésünk pusztán arra irányult, hogy van-e a megkérdezettnek az adott helyzetekben olyan kapcsolata, akitől segítséget kérhet. A következökben a társas támogatottság ilyen értelemben vett változásairól lesz szó Nyíregyháza felnőtt népességét illetően.

\begin{tabular}{|l|c|c|c|c|c|}
\hline $\begin{array}{c}\text { Van olyan családtagja/rokona, aki segítséget } \\
\text { nyújt/nyújtott... }\end{array}$ & 2008 & 2010 & 2012 & 2015 & 2018 \\
\hline hivatalos ügyintézéshez? & $\mathbf{5 0}$ & 50 & 55 & $\mathbf{5 1}$ & 65 \\
\hline iskoláztatással, továbbtanulással kapcsolatban? & 18 & 20 & 22 & 28 & 41,5 \\
\hline jó állás, munkahely megszerzésében? & n.a. & 25 & 29 & 27 & 41 \\
\hline betegség esetén jó orvos találásában? & 47 & $\mathbf{5 5}$ & $\mathbf{6 0}$ & 43 & $\mathbf{7 3}$ \\
\hline
\end{tabular}

1. táblázat: Társas támogatottság a családtól, rokonoktól 2008-2018.

A családtagok, rokonok támogatását elemezve megállapíthatjuk, hogy egyre erősödő támogatottságról számoltak be a megkérdezettek a vizsgált évek során: minden kategóriában növekedett azok aránya, akik azt válaszolták, hogy van olyan családtagjuk, rokonuk, akiktöl segítséget kaptak vagy kérhetnek. (1. táblázat) 
Ha ugyanezeket a kérdéseket megvizsgáljuk a barátok, rokonok támogatása oldaláról, megállapíthatjuk, hogy szinte minden kategóriában lineárisan növekedett azok aránya, akik azt mondták, hogy van olyan barátjuk, vagy ismerősük, akitől segítséget kaptak vagy adott esetben kérhetnek. A jó orvossal való kapcsolat esetében láthatunk egy csökkenést 2015-ben, majd egy erőteljes növekedést 2018-ra. (2. táblázat)

\begin{tabular}{|l|c|c|c|c|c|}
\hline $\begin{array}{c}\text { Van olyan barátja, ismerőse aki segítséget } \\
\text { nyújt/nyújtott... }\end{array}$ & 2008 & 2010 & 2012 & 2015 & 2018 \\
\hline hivatalos ügyintézéshez? & 30 & 40 & 42 & 35 & 43 \\
\hline iskoláztatással, továbbtanulással kapcsolatban? & 19 & 16 & 19 & 20 & 27 \\
\hline jó állás, munkahely megszerzésében? & n.a. & 30 & 30 & 32 & 43 \\
\hline betegség esetén jó orvos találásában? & 33 & 45 & 42,5 & 33 & 50,5 \\
\hline
\end{tabular}

2 táblázat: Társas támogatottság a barátoktól, ismerősöktől 2008-2018.

Adataink szerint az látható, hogy Nyíregyházán egyre növekszik azok aránya, akik úgy vélik, hogy mind családtagjaikra, rokonaikra, mind barátaikra, ismeröseikre számíthatnak bizonyos élethelyzetekben. A mikrotársadalmi szolidaritás, mely a társadalmi integráció fontos része, növekedni látszik a városban a mért kérdések mentén.

\section{Találkozás, beszélgetés gyakorisága a rokoni és nem rokoni kapcsolatokkal Nyíregyházán 2008 - 2018}

A társas kapcsolatok felmérése kiterjedt a különböző típusú kapcsolatokkal (rokonok, barátok, szomszédok) való találkozás, beszélgetés gyakoriságának vizsgálatára is, hiszen a kapcsolattartás gyakorisága lényeges mutatója lehet az adott kapcsolat erősségének. Azért indokolt a feltételes mód használata, mert azon túl, hogy az emberek nyilvánvalóan szívesebben találkoznak gyakran olyan másokkal, akiket kedvelnek és szeretik a társaságukat, vannak azonban olyan gyakori találkozások, beszélgetések is, melyeket nem válogathatunk meg. A szomszédokkal vagy munkatársakkal való kapcsolat erőssége félreértelmezhető, ha például csak a találkozási gyakoriságot vesszük alapul (Marsden-Campbell, 1984). A fizikai közelség gyakran generál gyakori találkozást (pl. szomszédok).

Kutatásunkban azt vizsgáltuk, hogy a megkérdezettek milyen gyakran beszélgetnek szomszédaikkal, illetve, hogy milyen gyakran találkoznak barátaikkal, rokonaikkal, akik máshol élnek (nem ugyanabban a háztartásban), mint ők. A fentebb említettek miatt, a szomszédokkal való találkozás gyakorisága helyett tehát inkább arra kérdeztünk rá, hogy milyen gyakran beszélgetnek a megkérdezettek szomszédaikkal. A beszélgetés folytatása intimebb, bizalmasabb, erősebb kapcsolatnak minősül, mint a találkozás. Azokkal a barátokkal, és rokonokkal, akik nem élnek a megkérdezett közelébe, a találkozás gyakoriságára kérdeztünk rá, hiszen itt a fizikai távolság áthidalására tett „erőfeszítés” (ti. meg kell szervezni a találkozást, el kell menni valahová, vendégül kell látni, stb.) utalhat a kapcsolat erösségére. 


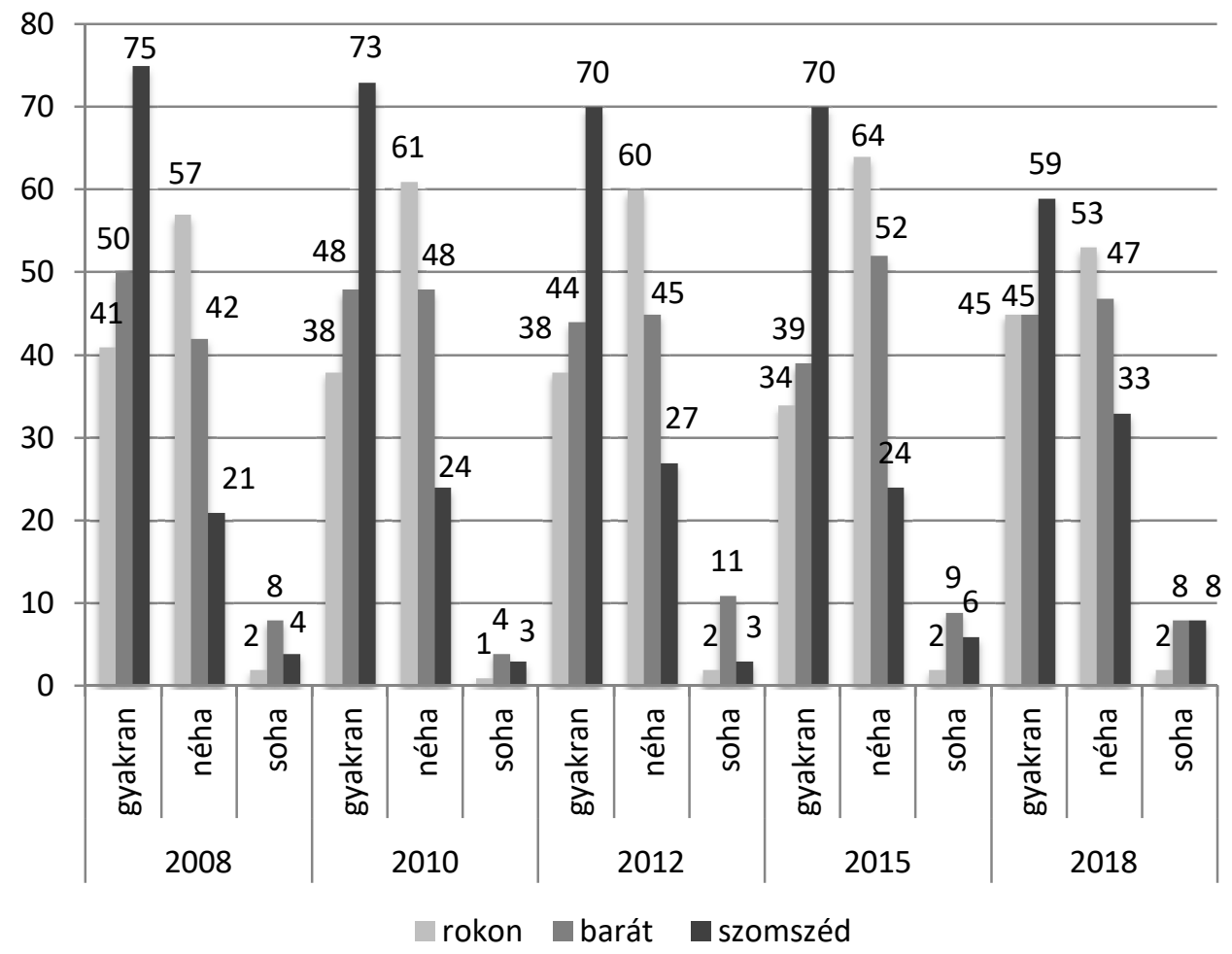

Forrás: Nyíregyháza életminősége, 2008, 2010, 2012, 2015, 2018

4. ábra: A rokoni és nem rokoni kapcsolatokkal való találkozás/beszélgetés gyakorisága 2008-2018.

Gyakorinak tekintettük a mindennapi és heti rendszeres találkozást, beszélgetést. A „néha” kategóriába a legalább havonta történő találkozás, beszélgetés került. Ezek alapján megállapítható, hogy a nyíregyházi megkérdezettek körében a kapcsolattartásra azokkal a rokonokkal, akik nem élnek velük leginkább a havi rendszeres találkozás a legjellemzőbb minden vizsgált évben (2008-ban 57\%, 2010-ben 61\%, 2012ben $60 \%$, 2015-ben 64\%, 2018-ban 53\%). A rokonokkal való gyakori kapcsolattartás a legutóbbi mérés során elérte, sőt, meghaladta a 2008-as arányt (2018-ban 45\%, 2008-ban 41\%), a 2010-2015 időszakot jellemző csökkenés után tehát növekedés látszik. (4. ábra)

A barátokkal való kapcsolattartásra jellemzően gyakran, de legalább havonta sor kerül. A különböző vizsgálati időpontokban azonban vannak eltérések: míg 2010ben, 2012-ben szinte teljesen megegyezett a barátokkal való gyakori és legalább havi rendszeres találkozás megoszlása, addig 2008-ban inkább a gyakoribb, 2015ben pedig inkább a ritkuló találkozási gyakoriságok sürüsödtek fel a válaszadók körében. A 2018-as mérés azt a tendenciát látszik megtörni, hogy míg 2008-ban a barátokkal való gyakori (mindennapos, vagy heti több alkalom) kapcsolattartás volt jellemző, 2010-2012 között a gyakori és a havi rendszeres találkozás gyakorisága kiegyenlítődött, majd 2015-re átbillent az inkább havi találkozási gyakoriság felé. Ez 
a gyakoriság a 2018-as mérésre újra kiegyenlítődött, közel azonos a barátaikkal gyakran és legalább havonta találkozók aránya.

A szomszédokkal való beszélgetés gyakorisága évről évre csökken, pontosabban egyre kisebb azok aránya, akik mindennap, vagy hetente 1-2 alkalommal beszélgetnek szomszédaikkal. Míg 2008-ban 75\% volt azok aránya, akik gyakran beszélgettek a fizikailag közel lévő szomszédaikkal, ez az arány 2018-ra csupán 59\%. A csökkenéssel párhuzamosan növekedett azok aránya, akik ritkábban, illetve azoké, akik soha nem beszélgetnek szomszédaikkal. Ez utóbbi a 2008-ban mért 4\%-ról a duplájára $(8 \%)$ növekedett.

\section{Magántársasági összejövetelek 2008-2018}

A magántársasági összejövetelek kapcsán a megkérdezettek vendégségbe járási, vendégfogadási és szórakozni járási szokásait, pontosabban gyakoriságát vizsgáljuk évről évre Nyíregyháza felnőtt népessége körében. Ezek a szokások jól mutatják azt, hogy a megkérdezettek milyen informálisabb kapcsolatkörökhöz tartoznak, illetve hogyan ápolják az ilyen típusú kapcsolataikat. A magántársasági összejövetelek általában szimpátia, vagy közös cél, vagy csupán megszokás révén szerveződnek és jellemzően olyan kapcsolatokat is tartalmaznak, melyek színesítik, bővítik az egyének kapcsolati tőkéjét.

A megkérdezettek minden vizsgált évben leginkább a gyakori vendégségbe menés szokásával jellemezhetők, azaz legalább havi rendszerességgel járnak vendégségbe. Általában a megkérdezettek fele jár gyakran vendégségbe, de az arány 2012 óta folyamatosan növekszik. 2018-ban látjuk a legmagasabb gyakoriságot, amikor a megkérdezettek 60\%-a mondta azt, hogy legalább havonta jár vendégeskedni. (5. ábra)

A gyakori vendégfogadás is hasonló képet mutat: 2012 óta folyamatosan növekszik azok aránya, akik legalább havi rendszerességgel vendégeket fogadnak (2012ben 56\%, 2015-ben 59\%, 2018-ban 66\%). Ezzel párhuzamosan 2012 óta folyamatosan csökken azok aránya, akik a „néha” kategóriába sorolhatók vendégfogadás tekintetében, illetve azoké, akik soha nem fogadnak vendéget. (5. ábra)

A gyakori szórakozni járók aránya 2012 óta folyamatosan növekszik a vizsgált mintában, 2018-ban már majdnem minden második megkérdezett (48\%) mondta azt, hogy legalább havonta eljár szórakozni. A ritkán, azaz évente néhányszor szórakozni járók aránya szinte mintsem változott az elmúlt tíz évben, általában a válaszadók negyede tartozik ide. A szórakozni soha nem járók aránya a kezdetben jellemző ingadozás (2008-ban 45\%, 2010-ben 32\%, 2012-ben 43\%) után 2012-tól folyamatos csökkenést mutat (2015-ben 32\%, 2018-ban 25\%). (5. ábra) 


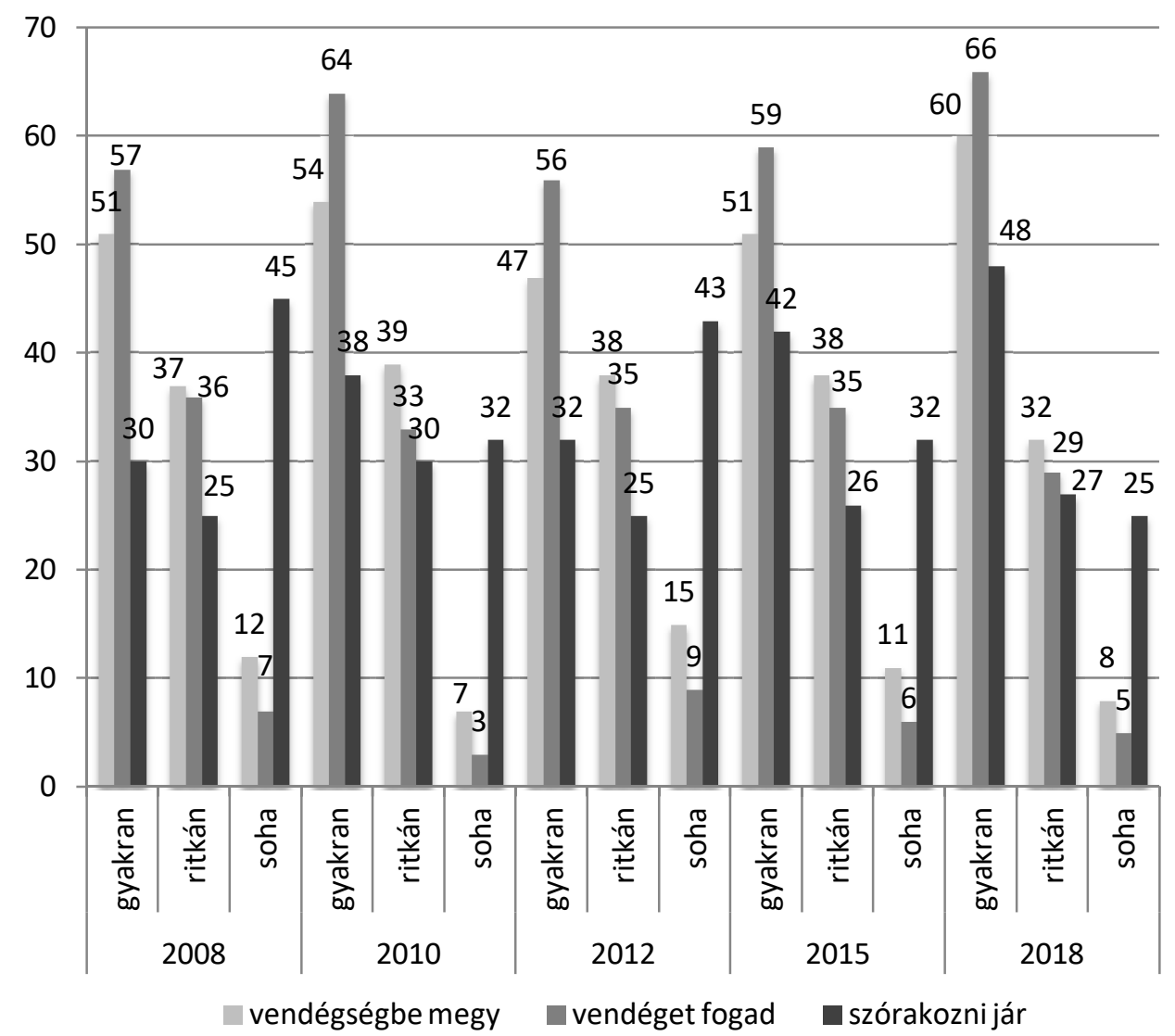

Forrás: Nyíregyháza életminösége, 2008, 2010, 2012, 2015, 2018

5. ábra: Magántársasági összejövetelek, 2008-2018.

\section{Szervezeti tagság, 2008-2018}

Az informálisabb magántársasági összejövetelek mellett évről évre vizsgáljuk a nyíregyházi felnőtt népesség szervezeti tagságának alakulását is. A szervezett közösségekre jellemző, hogy a magántársaságokkal ellentétben itt már lehetnek rögzített szabályok, müködési normák, stb., melyek élesebb keretet adhatnak a közösen eltöltött idönek. A szervezeti tagságot minden vizsgálati évben úgy mértük, hogy felsoroltuk a szóba jöhető szervezeti típusokat a sportklubtól kezdve a müvészeti csoportokon át a vallási közösségekhez vagy akár valamelyik párthoz való csatlakozást vizsgálva.

Az adatok alapján először is érdemes azt leszögezni, hogy a város felnőtt lakosságának jelentős része nem tartozik semmiféle szervezett közösséghez. Bár ez az arány az elmúlt tíz évben mutat némi csökkenést, ez nem nevezhető jelentősnek. Különösen, ha megfigyeljük: 2015-höz képest egyáltalán nem változott a szervezeti tagság aránya $(27,5 \%)$. (3. táblázat) 


\begin{tabular}{|c|c|c|c|c|}
\hline $\mathbf{2 0 0 8}$ & $\mathbf{2 0 1 0}$ & $\mathbf{2 0 1 2}$ & $\mathbf{2 0 1 5}$ & $\mathbf{2 0 1 8}$ \\
\hline 75 & 73 & 70 & 72,5 & 72,5 \\
\hline
\end{tabular}

3. táblázat: Nem tartozik semmilyen klubhoz, szervezethez (\%).

Azon válaszadókat tovább vizsgálva, akik tartoznak valamilyen szervezethez, elmondható, hogy az elmúlt tíz évben ha mininálisan is, de növekedett a sportklubhoz tartozók aránya. Alacsony részvétellel stagnál a helyi szomszédsági csoportokhoz, jótékonysági szervezetekhez, müvészeti csoportokhoz tartozók aránya. Magasabb részvételi aránnyal, de ugyancsak stagnál a szabadidős klubokhoz való tartozás gyakorisága. A megkérdezettek körében alacsonyan stagnál a párthoz való tartozás is. A vallási közösségekhez tartozás gyakorisága az eleinte mért növekedés után 2012-től folyamatosan csökken. (6. ábra)

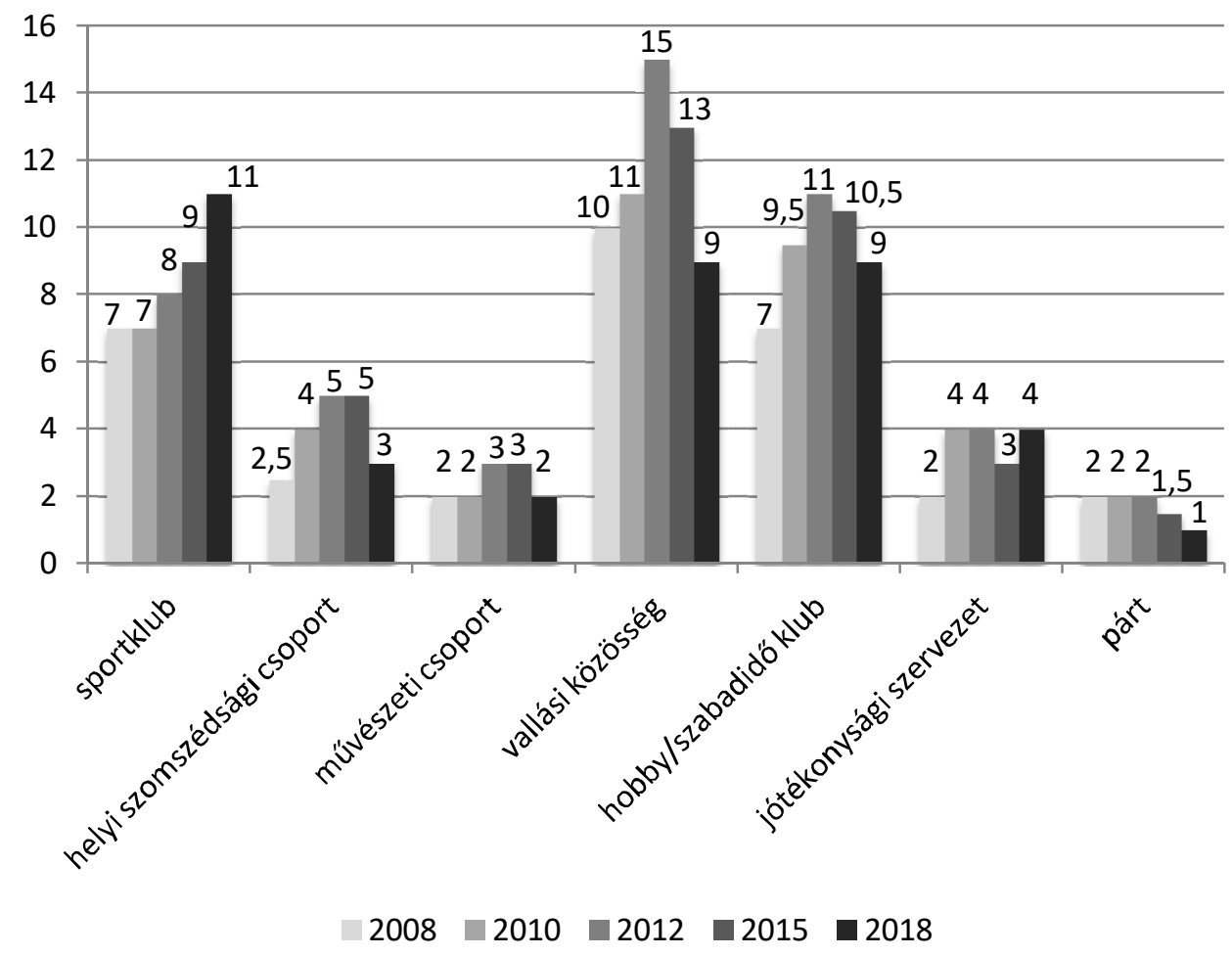

Forrás: Nyíregyháza életminősége, 2008, 2010, 2012, 2015, 2018

6. ábra: „Tagja-e Ön valamilyen klubnak vagy szervezetnek?” 2008-2018.

\section{Összefoglalás}

A társas kapcsolatok föbb jellegzetességei 2018-ban: a megkérdezettek átlagosan 5 barátról számoltak be, ami eltér a 2015-ben mért országos átlagtól, ahol 3 barátot 
mértek. A különböző korcsoportokban jelentősen eltér a barátok száma: a fiatalok lényegesen több baráttal rendelkeznek, mint a többi korosztály. A jelenség azonban megegyezik az országos tendenciákkal. A baráttal nem rendelkező arány 2018-ban $11 \%$ volt, de a baráthalmozó, azaz akiknek legalább tíz barátjuk van, ugyancsak $10 \%$-ban voltak jelent a vizsgált mintában.

A partnerkapcsolatban élők arányát vizsgálva azt tapasztaltuk, hogy negyven év alatt még a nök nagyobb hányada él partnerkapcsolatban, ötven év fölött viszont jelentősen csökken körükben a társsal élők aránya. A 70 éves és idősebb válaszadók esetében látható a legnagyobb különbség: a férfiak 84\%-a, míg a nöknek csupán 17\%-a él társsal ebben az életkorban. Ennek magyarázata alapvetően a férfiak halandósági adataiban keresendő. Az adatok nem térnek el jelentősen a 2015-ben országos reprezentatív mintán végzett kutatás eredményeitől (Albert-Dávid, 2016).

A társas kapcsolatok föbb jellegzetességei 2008-2018 között: a vizsgált tíz év során az átlagos barátok számát tekintve ingadozást figyelhettünk meg: legmagasabb barátszámot 2010-ben mértünk, mikor a megkérdezett felnőtt népesség átlagosan 6 barátról számolt be. Legkevesebbet 2015-ben mértünk, ekkor 4,7 volt az említett barátszám. A jelenség azonban nem szokatlan, hiszen a hazai vonatkozó vizsgálatok is hasonló mozgásokat detektáltak. A baráttal nem rendelkezők aránya viszonylag statikus az első négy mérési hullámban (20-21-16-20\%), míg legutóbbi mérés eltér el az előzőektől: a 2018-as adatok szerint a megkérdezetteknek tizede sorolható a baráttal nem rendelkezők körébe, ami jelentős csökkenést jelent. Az is megfigyelhető, hogy soha nem volt ilyen magas az 1-4 baráttal rendelkezők aránya, mint 2018ban, azaz csökkent a baráttal nem rendelkezők és nőtt a legalább egy baráttal bíróké, ami mindenképpen egy pozitív jelenség.

A társas támogatottságot vizsgálva megfigyelhető, hogy mind a családtagok, rokonok, mind a barátok, ismerösök támogatása leginkább a jó orvos megtalálásában a legjelentősebb. A rokonokra támogatására a hivatalos ügyek intézésében is sokan számítanak. Legkevésbé minden vizsgált évben az iskoláztatással és a munkahely találással kapcsolatban számíthat mind a rokoni, mind a baráti támogatásra a vizsgált populáció, de azok aránya, akik számíthatnak ilyen jellegü segítségre, évről évre növekszik.

A rokonokkal és barátokkal való kapcsolattartás gyakorisága pozitívan változott az elmúlt 10 évben, hiszen az előző évek csökkenő tendenciája után 2018-ra újra növekszik azok aránya, akik rokonaikkal, barátaikkal gyakran, azazn legalább heti rendszerességgel találkoznak. A szomszédokkal való beszélgetési gyakoriságra éppen ellenkező tendencia érvényesül: 2018-ra jelentősen csökkent azok aránya, akik szomszédaikkal legalább hetente rendszeresen beszélgettek.

Általában a megkérdezettek fele jár gyakran vendégségbe, de az arány 2012 óta folyamatosan növekszik. 2018-ban látjuk a legmagasabb gyakoriságot, amikor a megkérdezettek 60\%-a mondta azt, hogy legalább havonta jár vendégeskedni. A gyakori vendégfogadás is hasonló képet mutat: 2012 óta folyamatosan növekszik azok aránya, akik legalább havi rendszerességgel vendégeket fogadnak (2012-ben 56\%, 2015-ben 59\%, 2018-ban 66\%). A gyakori (havonta) szórakozni járók aránya 2012 óta folyamatosan növekszik a vizsgált városlakók körében.

A város felnőtt lakosságának jelentős része nem tartozik semmiféle szervezett közösséghez. Bár ez az arány az elmúlt tíz évben mutat némi csökkenést, ez nem 
nevezhető jelentősnek. Különösen, ha megfigyeljük: 2015-höz képest egyáltalán nem változott a szervezeti tagság aránya $(27,5 \%)$.

A fentebbi folyamatok alapján Nyíregyháza felnőtt lakosságát az egyre tágasabb és gyakoribbá váló kapcsolatokkal jellemezhetjük: 1. viszonylag sok baráttal rendelkeznek, és csökken a baráttal nem rendelkezők aránya, 2. jellemző a növekvő társas támogatottság mind rokoni, mind baráti, ismerősi körben, 3. sürübbé váló kapcsolattartás a rokonokkal, barátokkal, 4. növekő magántársasági tendencia.

Ugyanakkor erőteljes csökkenés figylehető meg a szomszédsági kapcsolatokban, illetve a szervezeti tagságban nem történt jelentős elmozdulás: 1. csökkenő beszélgetési gyakoriság a szomszédokkal, 2. stagnáló szervezeti tagság.

\section{Felhasznált irodalmak jegyzéke:}

1. Albert, F.- Dávid, B. (2001): Ha elszakad a háló... A hajlkéktalanság kapcsolathálózati megközelítésben. Budapest: Új Mandátum Kiadó.

2. Albert F.-Dávid B. (2007): Embert barátjáról. A barátság szociológiája. Budapest: Századvég.

3. Albert F.-Dávid B. (2016): A magyarországi kapcsolathálózati struktúrák jellemzői 2015-ben. socio.hu 2016/3

4. Fábián G., Huszti É., Hüse L., Takács P. (2018): Életminőség Nyíregyházán. A nyíregyházi nagymintás társadalomkutatások első négy hulláma a megyeszékhelyen. Szabolcs-Szatmár-Beregi Szemle 53/3: 83-102.

5. Granovetter, M. S. (1973): The Strenght of Weak Ties. American Journal of Sociology, 78:1360-1380

6. Huszti É. (2012): Társas kapcsolatok: Családi, rokoni, baráti kapcsolatok Nyíregyháza lakói körében 2008-2010. ACTA MEDICINAE ET SOCIOLOGICA 3:(ksz.) pp. 155-176.

7. Huszti É. (2014): Társas kapcsolatok Nyíregyházán. ACTA MEDICINAE ET SOCIOLOGICA 5:(12-13) pp. 143-165.

8. Huszti É. (2015b): Mondd meg, kikkel töltöd az idődet, s megmondom ki vagy. A társas támogatást nyújtó személyes kapcsolati háló néhány jellemzője és múködése a Nyíregyházi járásban. Acta MedSoc Vol.6. No. 18-19.

9. Huszti É., Hüse L., Takács P., Fábián G., (2018): A „Nyíregyháza Életminősége 2018" vizsgálat és a kutatás módszertana. Acta Medicinae et Sociologica Vol.9. No.27. 7-18.

10. Lin, N. (2008): A Network Theory of Social Capital. In: Castiglione D., Van Deth,

11. Marsden, P.V. - Campbell, K.E. (1984): Measuring Tie Strenght. Social Forces, 63. pp. 482-501.

12. Utasi Á. (2008): Éltető Kapcsolatok - A kapcsolatok hatása a szubjektí életminőségre. Budapest: Új Mandátum Könyvkiadó. 